\title{
Notes on the Biology of Tellina tenuis da Costa.
}

\author{
By \\ A. C. Stephen, B.Sc. \\ Royal Scottish Museum, Edinburgh \\ (And at the Marine Station, Millport, N.B.).
}

With 5 Figures in the Text.

\section{CONTENTS.}

I. Introduction and Methods employed $\quad . \quad$. $\quad . \quad$. $\quad$. 683

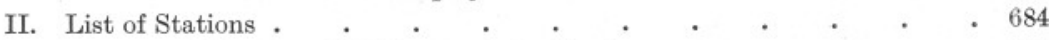

III. Range and Density of Tellina tenuis in the Area . $\quad . \quad$. $\quad . \quad$ - 685

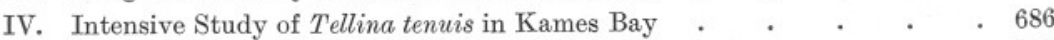

(a) Density at each intertidal station . . . . . . . 686

(b) Distribution according to size . . . . . . . . 6866

(c) Rate of growth . . . . . . . . . . . 6888

V. Comparison of the Size-frequencies of Tellina tenuis in Kames Bay with

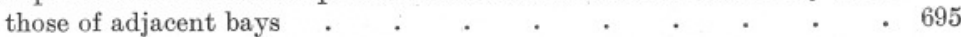

VI. Comparison of the Distribution of Tellina tenuis and Tellina fabula in

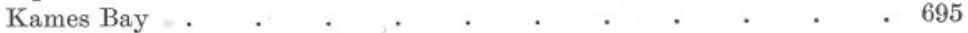

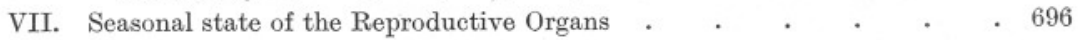

VIII. Appearance and distribution of the young brood . . . . . . . . 696

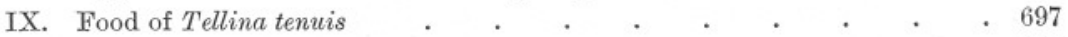

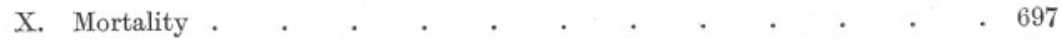

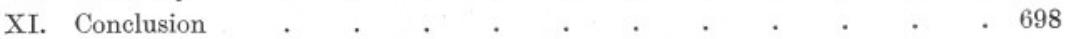

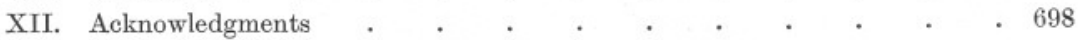

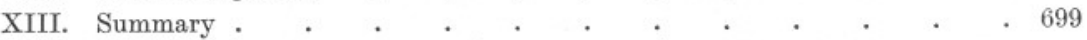

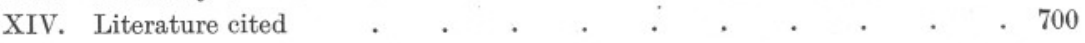

\section{Introduction and Methods employed.}

THE study of the rate of growth of the invertebrate population of the sea and of the amount and time of deposition of the broods on the seabottom is of importance both for investigations on the economy of the sea and in relation to fishery problems. It is not usual, however, to obtain at one time sufficient numbers of a particular species as are necessary for studies on such questions as the rate of growth of the individual, or of the number of year groups composing the population. When, therefore, a quantitative digging in Kames Bay on the Cumbrae, on the Firth of Clyde, revealed sufficiently large numbers of Tellina tenuis living in the sand, an opportunity suggested itself for attempting such studies. A general 
survey of the various bays in the Cumbrae was made, but Kames Bay was selected for intensive study, both on account of its accessibility and its richness in Tellina tenuis. A number of stations was fixed in the bay above and below low-water mark of spring tides, and these were examined on six different occasions from the last week of September, 1926, to the first week of October, 1927, so that the samples cover a complete year in the life of the species, and enable the growth of at least one year group to be traced accurately. At the same time parallel observations were made in other areas in the neighbourhood.

The method of sampling differed according as the stations lay in the intertidal zone or below low-water mark. In the first case a square with sides of half a metre was marked out on the sand and then dug out to a depth of about $15 \mathrm{~cm}$. with a spade, experiment having shown that digging to this depth would capture all the Tellina tenuis on the ground. When dug out the sample was placed on a sieve of perforated zinc with circular holes $2 \mathrm{~mm}$. in diameter and washed.

Below low-water mark a Robertson bucket dredge was used to collect the samples, and sufficient sand or mud collected to fill a $20 \mathrm{~cm}$. cube. This, also, was washed on the $2 \mathrm{~mm}$. sieve. Examinations for young broods were carried out with a sieve having holes $1 \mathrm{~mm}$. in diameter.

The ratio of the quantity of sand in a $\frac{1}{4} \mathrm{sq}$. m. dug to a depth of $15 \mathrm{~cm}$. to that of a $20 \mathrm{~cm}$. cube is about $4 \cdot 7$ to $1 \cdot 0$. Where the two methods of digging and of dredging with the bucket dredge were tested, one against the other at the same station, the catches were in about the theoretical proportions, but the dredge, owing to its skimming action, contained a relatively higher proportion of small individuals. On this account the results got by the two methods, expressed as percentages of the total catch, are discussed separately. The measurement of Tellina tenuis used in the tables is that of the greatest antero-posterior length in mm. taken to the $\mathrm{mm}$. above, i.e. all specimens between $7 \cdot 1$ and $8 \mathrm{~mm}$. are included in the $8 \mathrm{~mm}$. column.

\section{List of Stations.}

The stations in Kames Bay at which Tellina tenuis was secured are as follows :-

Stn. 1 High-water mark, neap tides.

, la 20 yards below Stn. 1 .

", $240 \quad, \quad, \quad$, ,

", $380 \quad, \quad, \quad$,

" 4120, , , ,

"5 $160, \quad$, , , low-water mark, spring tides.

$\therefore 6$ Approx. 2 fms. at high water, neap tides.

" $7 \quad 3$, " , " , " ,

" $8 \quad$ " 5 , " $, \quad, \quad$, 
The bottom at all these stations consists of fine clean sand, practically all passing through a $1 \mathrm{~mm}$. sieve, with a trace of mud only at Stn. 8 .

In addition the following bays in the Cumbrae and neighbourhood were worked for samples of Tellina tenuis on one or more occasions.

1. Garrison Bay. A small sandy bay to the west of Kames Bay, one station at L.W.M.

2. Fintry Bay. A large sandy bay on the west of the Cumbrae, stations at mid-tide and L.W.M.

3. White Bay. A small sandy bay on the north of the Cumbrae, stations at mid-tide and L.W.M.

4. Balloch Bay. A large muddy bay on the east side of the Cumbrae, three lines of stations at H.W.M., mid-tide, and L.W.M.

5. Castle Bay. A small sandy bay on the Little Cumbrae, one station at L.W.M.

6. Hunterston Sands. A line of stations up the Hunterston Sands on the Ayrshire coast opposite Keppel. Stations at L.W.M. and at 100, 300 , and 750 yards up from it. This last station being about threequarters way up the beach.

\section{Range and Density of Tellina tenuis.}

Tellina tenuis is the dominant form in certain sandy bays in the Cumbrae and its neighbourhood. It ranges from a little below H.W.M. to a depth of 3-4 fm., with its maximum concentration in the region of L.W.M. spring tide.

The density in certain of the bays is very high, and the following list of some of the densities per $\frac{1}{4} \mathrm{sq}$. $\mathrm{m}$. found during the investigations will give an idea of the abundance of this species.

\section{TABLE 1.}

Table showing the maximum density, per $\frac{1}{4}$ sq. m., of Tellina tenuis in certain bays in the Cumbrae and neighbourhood.

$\begin{array}{lcc}\text { Kames Bay. } & \text { On one occasion } & 1897 \\ \text {, ", Usual at L.W.M. } & \text { 760-1000 } \\ \text { White Bay } & 242 \\ \text { Balloch Bay } & 218 \\ \text { Castle Bay, Little Cumbrae } & 312 \\ \text { Hunterston Sands } & 765 \\ \text { Garrison Bay } & 265\end{array}$

These high numbers contrast markedly with those which I have found in the sands along the south shore of the Firth of Forth, where the best hauls, made at North Berwick and Cramond, gave only 15 and 8 Tellina tenuis, respectively, per $\frac{1}{4}$ sq. m. 


\section{Intensive Study of Tellina tenuis in Kames Bay.}

\section{(a) Density at each intertidal Station.}

In Kames Bay the density of Tellina tenuis decreases from L.W.M. to H.W.M. in a regular manner. In September, 1926, for example, the density per $\frac{1}{4}$ sq. m. at each station above L.W.M. was as follows :-

\section{TABLE 2.}

$\begin{array}{ccccccc}\text { Stn. } & \mathbf{1} & \text { 1a } & 2 & 3 & 4 & 5 \\ \text { No. of Tellina tenuis } & 0 & 14 & 132 & 205 & 473 & 822\end{array}$

In all subsequent observations a similar result was obtained, except that the numbers of Tellina tenuis at Stns. 4 and 5 were usually rather closer.

\section{(b) Distribution according to Size.}

The distribution according to size is also very remarkable, and the uniformity of the physical conditions in the area may be, in part, the cause. The bay is long and narrow, the slope is gentle, and the bottom consists of fine sand with a high and uniform water content. An estimate of the water content was made by Mr. Elmhirst, and the percentage loss of weight when a sample of wet sand from each station was dried is as follows :-

\section{TABLE 3 .}

$\begin{array}{ccccccc} & \begin{array}{c}\text { Wind drifted } \\ \text { sand above }\end{array} & \text { Stn. } & \text { Stn. } & \text { Stn. } & \text { Stn. } & \text { Stn. } \\ \text { H.W.M. } & \mathbf{1} & 2 & 3 & 4 & 5 \\ \text { \% loss } & 17 \cdot 4 & 19 \cdot 9 & 20 & 20 & 20 & 20\end{array}$

The texture of the sand is very uniform and, unlike the sand of most of the other bays examined in the neighbourhood, is not mixed with large quantities of broken shells. The distribution of size-frequencies at the various stations in Kames Bay may represent the normal one when the area exposed during ebb tide is sufficiently entensive and uniform in slope to permit of zoning. In most bays the short slope, or sand banks, or constitution of the bottom, or a combination of all these factors may make it difficult to trace the levels as clearly as in Kames Bay, or may obliterate the zoning normal in other areas.

During these investigations some fifteen to sixteen thousand individuals, mostly from Kames Bay, were measured, and in Table 7 (p.701) the percentage of the catch at each $\mathrm{mm}$. size is set out for the various stations. From this table it is evident that the larger individuals occur in the upper reaches of the bay, while the smaller sizes predominate at lower levels. The differences in density and size-frequency at the various stations are perhaps more clearly shown in Figure 1, where the actual collections of Tellina 


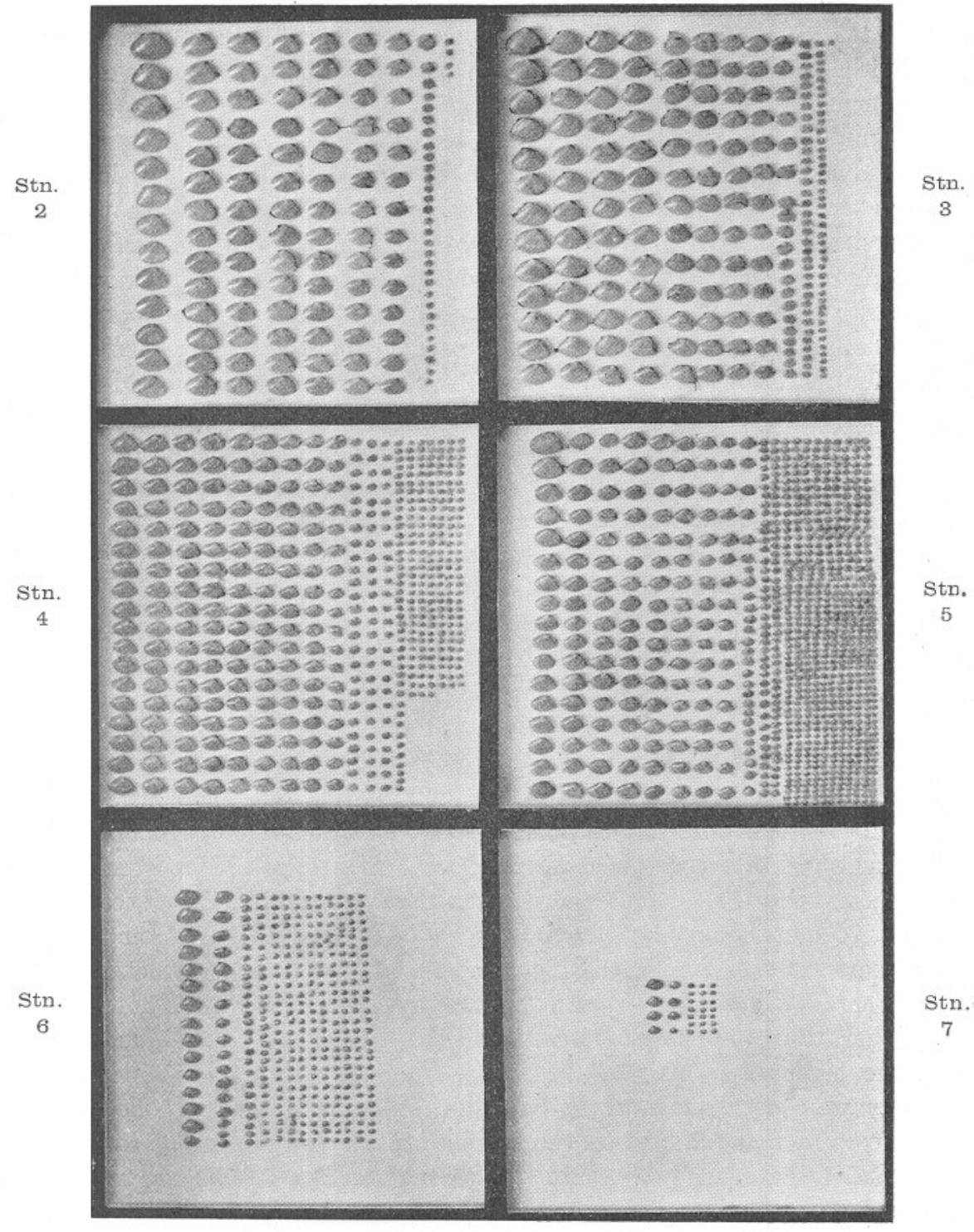

Fig. 1.-Photograph showing the actual numbers of Tellina tenuis taken in September, 1926.

Stns. $2,3,4,5$ on $\frac{1}{4}$ sq. metre.

Stns. 6,7 in a $20-\mathrm{cm}$. cube. 
tenuis made in September, 1926, at Stns. 2, 3, 4, and 5 in a $\frac{1}{4}$ sq. m. of sand dug to a depth of $15 \mathrm{~cm}$., and at Stns. 6 and 7 in a $20-\mathrm{cm}$. cube of sand collected by a bucket dredge, are shown. At Stn. 6, for example, few individuals over $7 \mathrm{~mm}$. were taken, while at Stn. 2 the majority of the specimens were from 13 to $15 \mathrm{~mm}$. in length.

Gemmill (9) found that in Mytilus edulis and Patella vulgata the individuals at higher levels were of smaller size than those at low levels, while the reverse is found for Tellina tenuis. He suggests that the differences of size at high and low levels are due to Patella and Mytilus feeding only when covered by the tide, and that therefore individuals from higher levels will have less time for feeding. The differences between Mytilus and Patella and Tellina are probably due to the fact that both Mytilus and Patella when the tide recedes are exposed to the air and must suspend most of their activities.

Segerstråle (10), working on Macoma baltica in a fjord at the Tvärminne Zool. Station, found only large specimens in the deepest parts of the fjord, but inshore both large and small ones were present. $\mathrm{He}$ suggests that this distribution of sizes may be due to migration. From the few investigations I have made on Macoma baltica it seems probable that along the Scottish coast the size distribution is similar to that of Tellina tenuis.

Table 7 (p. 701) also shows that the character of the hauls in Kames Bay above and below L.W.M. is quite different at all seasons. Below L.W.M. the population is composed only of individuals whose rate of growth and general size is apparently small. Stn. 8 may be considered, for all practical purposes, as marking the seaward limit of the species. The numbers taken at this station are small and range in size from 3 to $5 \mathrm{~mm}$. At Stn. 7 the numbers are higher than at Stn. 8, but at all seasons about $90 \%$ of the population was found to be under $7 \mathrm{~mm}$. At Stn. 6 the numbers are still higher, the population contains larger specimens, but even here few individuals over $7 \mathrm{~mm}$. are met with. At Stn. 5, however, the character of the catch changes, and the change is even more marked in the higher stations. At Stn. 5 the numbers per sq. m. reach the maximum concentration in the bay, and, from the method of collection, it is certain that all sizes on the ground are represented in the sample. At Stn. 4 the density approximates to that at Stn. 5, but the rate of growth is slightly increased. At Stns. 3 and 2 the density falls off rapidly, but the rate of growth increases considerably.

\section{(c) Rate of Growth.}

We may begin the study of the rate of growth of Tellina tenuis in Kames Bay at the stations above L.W.M., where growth, assuming that the 
population is more or less stationary, is fairly rapid, and deal later with the results from the stations below L.W.M. where growth is slower.

As may be seen from the figures for Stn. 5 (Table 7), the group of individuals at 3 to $4 \mathrm{~mm}$. in length formed about $80 \%$ of the population

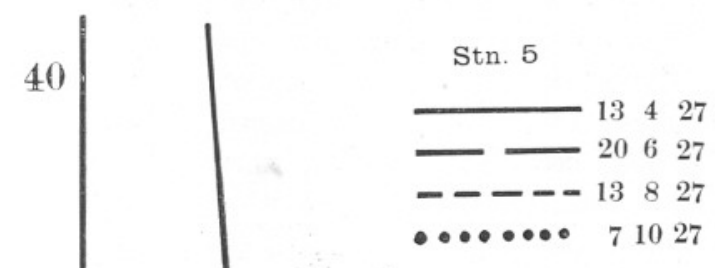


in September, 1926, and there is a hint of a second group at 8-9 mm. From September to April there is little growth, but from April onwards growth is fairly rapid (Fig. 2). By June the mode at $3 \mathrm{~mm}$. in April has shifted to $5 \mathrm{~mm}$., and that at $10 \mathrm{~mm}$. in April to $11 \mathrm{~mm}$. By August the mode at $5 \mathrm{~mm}$. in June has shifted to $6 \mathrm{~mm}$., while that at $11 \mathrm{~mm}$. remains about the same figure. There is in addition a third mode in the August curve marking the presence of the 1927 spat which had recently made its appearance on the ground. In August, 1927, when growth may be considered to have ceased for the year, there are three modes on the curve, at $3 \mathrm{~mm}$., $7 \mathrm{~mm}$., and $11 \mathrm{~mm}$., which might reasonably be taken as representing three year-groups, provided there is not more than one spatting season per annum. A comparison of the curve for September, 1926, with that of October, 1927 (Fig. 4), shows that this can hardly be the case, for it is evident that there is one year-group entirely missing. In the size-frequency curve for September, 1926, there is one mode at $3 \mathrm{~mm}$., as in October, 1927, but there is none at $7 \mathrm{~mm}$., as in October, 1927. Now we have actually traced the growth of two groups during the year from $3 \mathrm{~mm}$. and $9 \mathrm{~mm}$. in September, 1926, to $7 \mathrm{~mm}$. and $11 \mathrm{~mm}$. in October, 1927. In other words, the smaller sized group has grown $4 \mathrm{~mm}$. in length during the year, and the larger one $2 \mathrm{~mm}$. To assume that in 1926 growth was much more rapid than in 1927 does not seem the best way out of the difficulty, for that would mean a growth-rate in 1926 practically double that of 1927 . It seems much more reasonable to assume that the year-group at $7 \mathrm{~mm}$. in the October, 1927, curve is unrepresented on the September, 1926, curve, and that the group at $11 \mathrm{~mm}$. on the October, 1927, curve is poorly represented on the September, 1926, curve. The growth-rate being much higher at the upper stations, the absence, or poor representation, of these two groups becomes much more marked.

If, then, we accept the idea that one year-group is unrepresented in the curve for October, 1927, at Stn. 5, we may say that at L.W.M. in Kames Bay in October, 1927, there were four year-groups represented in the population, namely, the spat of $1927(0+$ group $)$, mostly 3 to $4 \mathrm{~mm}$. in length; the 1926 spat (1+group) ranged round $7 \mathrm{~mm}$; the missing 1925 spat $(2+$ group $)$, which would have ranged round $9 \mathrm{~mm}$. ; and lastly the 1924 spat $(3+$ group) ranged round $11 \mathrm{~mm}$. There may, of course, be a few representatives of older groups, but, if present, they form a very insignificant part of the population.

These figures indicate that since 1924 there have been alternate good and bad years of spat fall. For example, the $0+$ group in the autumn of 1927 is only about a third part that of the autumn of 1926, which is a very well-marked group, while the $0+$ group of 1924 is almost absent. Boysen Jensen (2) notes a similar occurrence in Danish waters where he has found that the spat of Syndosmya alba appears about every second year. 
The growth-rate of Tellina tenuis at Stn. 4 is similar to that at Stn. 5 (Table 7). There is the same high density, the same year-groups can be traced, but growth is a little more rapid. On the curves for October, 1927, for example, the modes are at 7.5 mm., $10 \mathrm{~mm}$., and $12 \mathrm{~mm}$. for

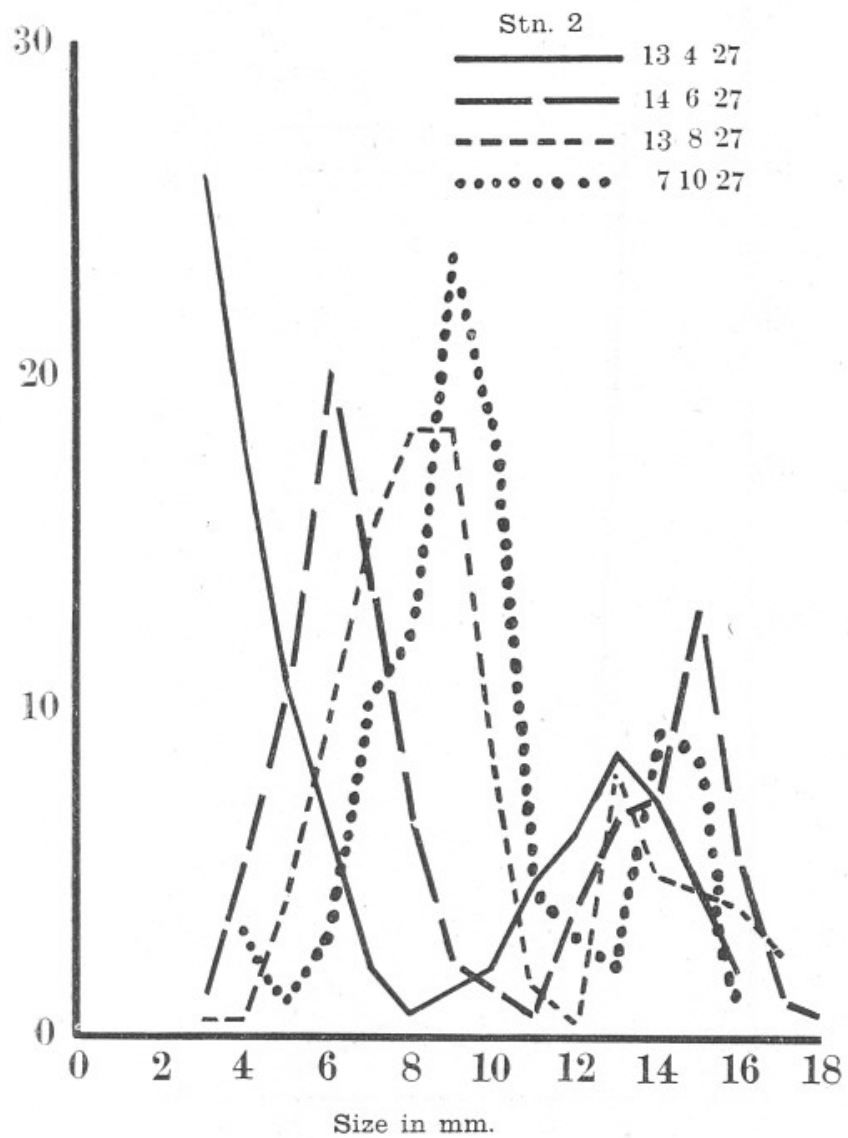

FIG. 3.-Graph showing the percentage (ordinate) of the catch at each mm. for Stn. 2 in April, June, August, and October, 1927.

Stn. 4, as compared with $7 \mathrm{~mm} ., 9 \mathrm{~mm}$., and $11 \mathrm{~mm}$. at Stn. 5 . As before the absence of the 1925 spat ( $2+$ group) is clearly marked.

There are noticeably few of the 1927 spat retained by the $2 \mathrm{~mm}$. sieve at Stn. 4, while they are present in numbers at Stn. 5, and this contrasts with the conditions found in the previous year, where, in September, 1926, they were numerous both at Stns. 4 and 5 (Table 7). The difference 
this year may be due to a retardation of the growth of the spat by the generally unfavourable conditions of 1927 .

The size-frequency tables for Stns. 3 and 2 differ considerably from those of the lower stations. The individuals are, on the whole, considerably

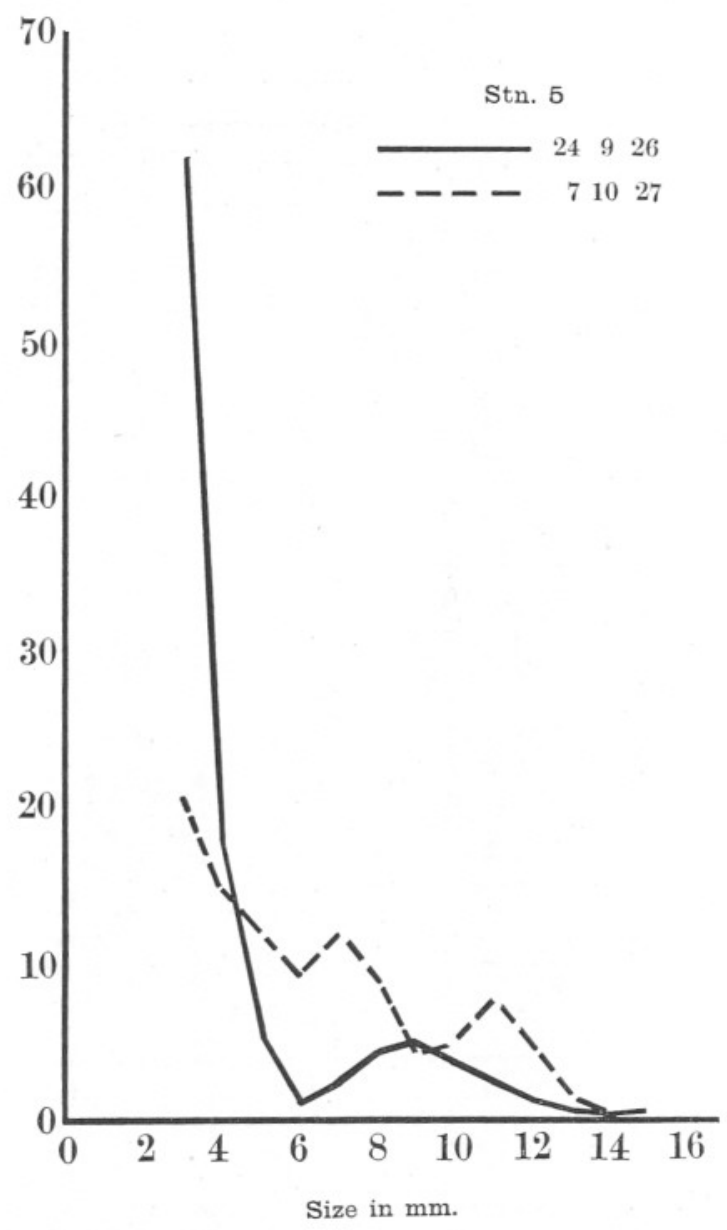

FIG. 4.-Graph showing the percentage (ordinate) of the catch at each mm. at Stn. 5 in September, 1926, and October, 1927.

larger, the rate of growth is more rapid, and the curves indicate a rather less compact group round the mean. For the latter peculiarity a reason may be suggested from an inspection of the figures for Stns. 3 and 2 in Table 7. The spat, as will be shown later, is probably deposited over a period and the earlier falls seem to be below L.W.M., but sooner or later 
some is deposited in the intertidal area as well. The earlier spat has still a short period of growth before winter sets in, e.g. in autumn there is a mode in the curves for Stns. 3 and 2 at $5 \mathrm{~mm}$., but during the winter large numbers of smaller individuals make their appearance at these stations, as is shown in Table 7 where the percentage of individuals at $3 \mathrm{~mm}$. in length

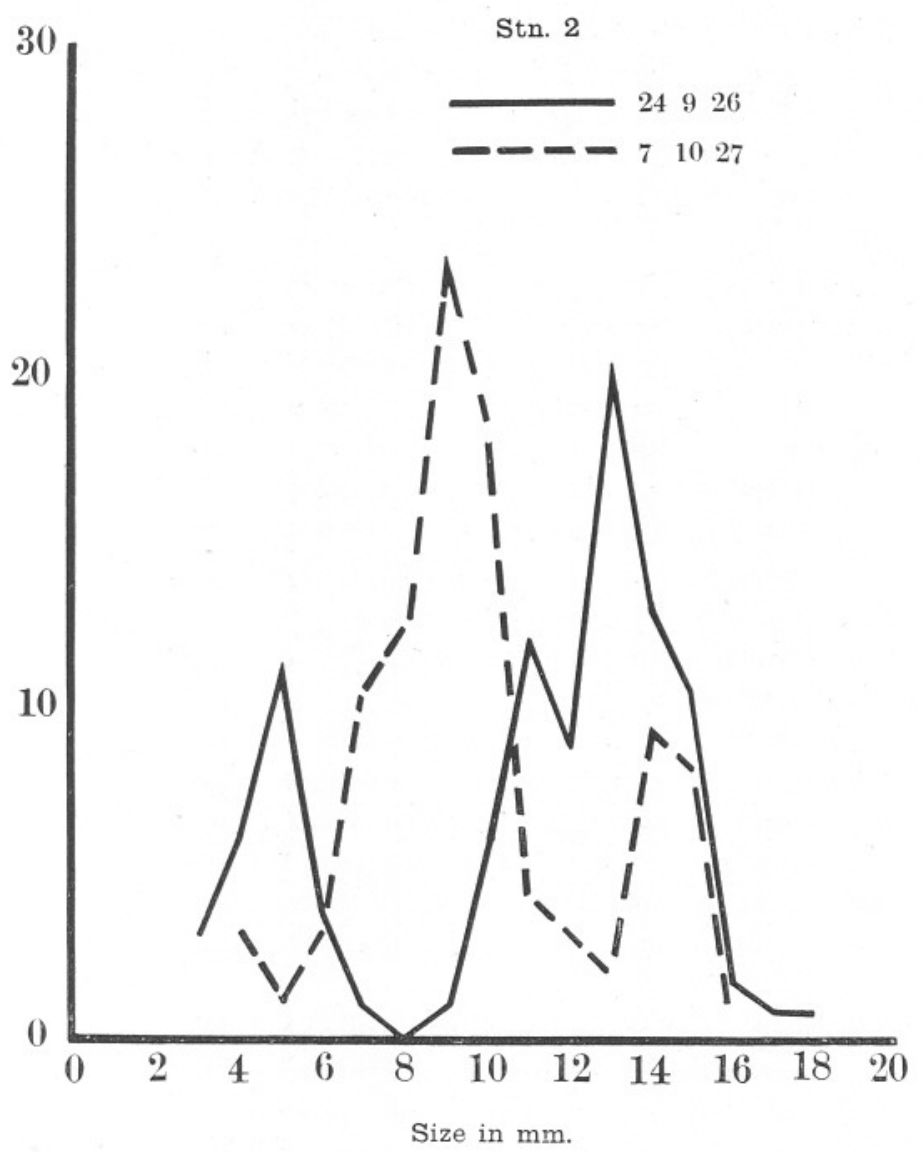

FIG. 5.-Graph showing the percentage (ordinate) of the catch at each mm. for Stn. 2 in September, 1926, and October, 1927

rises from $10 \%$ in September, 1926, to $13 \%$ in January, 1927, and to nearly $30 \%$ in April, 1927, at Stn. 3. At Stn. 2 a similar rise occurs. When, therefore, growth starts again in spring there are the rather larger individuals which have reached a size of $5 \mathrm{~mm}$. in the autumn, and the smaller ones at 3 and $4 \mathrm{~mm}$., and these two sets of individuals, growing at about the same rate, give the appearance of a double group whose 
limits lie close together. This increase of small individuals at Stns. 3 and 2 may be due either to a prolonged spat fall, or to a gradual movement of the animals themselves, or to a slight continuance of growth during the winter months. Until the history of the earlier stages of Tellina tenuis is worked out this must be left an open question.

Returning now to the figures for Stns. 3 and 2 (Table 7), it is seen that the density is markedly less at Stn. 3 than at Stn. 4 , and rather less at Stn. 2 than at Stn. 3. The individual growth is larger than at Stn. 5 (compare Figs. 3 and 4), but four-year groups can be traced as at Stn. 5. The absence of the $2+$ group (1925 spat) is again evident if we compare the curves for September, 1926, with those of October, 1927, for Stn. 2 (Fig. 5).

Stn. la marks for all practical purposes the upper limit of the species. The individuals here are smaller, and the density less, than at Stn. 2. The number of specimens taken in the samples has varied considerably, so no attempt is made to discuss the rate of growth at this level.

Turning now to the stations below L.W.M. we find that at Stn. 6 growth is slow and the modes lie close together. In this case it might have been better to have measured the specimens to the nearest half $\mathrm{mm}$. in order to separate the year groups. In October, 1927, (Table 7) the $0+$ group and $1+$ group are quite well marked at $3 \mathrm{~mm}$. and $6 \mathrm{~mm}$. respectively, while the $3+$ group might lie at $9-10 \mathrm{~mm}$. The missing $2+$ group would probably lie about $8 \mathrm{~mm}$.

With regard to Stn. 7 it is not possible, in the present state of our knowledge of the species, to give an accurate figure for the rate of growth of the individuals at this level nor a satisfactory reason for their permanent dwarf size. This station lies near the seaward limit of its range and conditions probably begin to prove adverse, but, on the other hand, at the landward limit individuals, if few, are of considerable size.

Davis $(\mathbf{3})$ and Ford (6) have given the results of their studies on the rate of growth of certain allied species of lamellibranchs from deep water, but in the present state of our knowledge it is not possible to draw comparisons between the rate of growth in Scottish waters and that in the Southern areas.

To summarise the remarks made on the rate of growth of Tellina tenuis in Kames Bay, we may say that the Tellina tenuis population is almost entirely composed of four-year groups, one of which is not well represented. At each station from $3 \mathrm{fm}$. to near H.W.M. the rate of growth is slightly different, being progressively more rapid as we proceed shorewards. Appended is a table showing the modes for each year-group at Stations 6 to 2 for the October, 1927, curves. 
TABLE 4.

\begin{tabular}{ccccc} 
& \multicolumn{4}{c}{ Year groups. } \\
Station. & $0+$ & $1+$ & $2+($ missing $)$ & $3+$ \\
6 & $3 \mathrm{~mm}$. & $6 \mathrm{~mm}$. & $8 \mathrm{~mm}$. & $9.5 \mathrm{~mm}$. \\
5 & $3 \mathrm{~mm}$. & $7 \mathrm{~mm}$. & $9 \mathrm{~mm}$. & $11 \mathrm{~mm}$. \\
4 & & $7.5 \mathrm{~mm}$. & $10 \mathrm{~mm}$. & $12 \mathrm{~mm}$. \\
3 & $4 \mathrm{~mm}$. & $8.5 \mathrm{~mm}$. & $11 \mathrm{~mm}$. & $14 \mathrm{~mm}$. \\
2 & $4 \mathrm{~mm}$. & $9.5 \mathrm{~mm}$. & $11.5 \mathrm{~mm}$. & $14.5 \mathrm{~mm}$.
\end{tabular}

V. Comparison of the Rate of Growth of Tellina tenuis in Kames BAY WITH THAT OF THE OTHER BAYS IN THE NEIGHBOURHOOD.

In Table 8 (p. 702) are given the size-frequencies at each mm., in percentage of the total, of Tellina tenuis for some of the other bays in the Cumbrae and its neighbourhood. As these collections were made for the purposes of the general survey no attempt is made to trace out the yeargroups till repeated observations, like those in Kames Bay, have been made, but the figures as they stand are interesting and suggestive. Growth is evidently more rapid in areas such as the Hunterston sands, White Bay, Garrison Bay, and Castle Bay, than in the corresponding levels in Kames Bay. The modes on the curves for these bays correspond rather to those of the curves for Stn. 2 in Kames Bay than to those of Stn. 5 as their position at, or near, L.W.M. would lead us to expect. Ford ( $(y)$ has found similar results for Syndosmya alba in Bigbury Bay and, he states that " the average size of the mollusc is greater when the numbers are fewer." The numbers in these other cases, with the exception of one haul on the Hunterston sands, correspond to those of Stns. 3 and 2 in Kames Bay, so it may be that the progressive changes in the rate of growth at the various stations in Kames Bay are determined not only by the actual position on the beach but also by the density of population, i.e. by the amount of food available for each individual.

The figures also suggest that in these other bays rather older year-groups are present than in Kames Bay, and that some of the individuals may be five, six, or even more years of age. In all these areas, however, the 1926 brood predominates as in Kames Bay.

Ford (8) has found a similar result in the case of Spisula elliptica, and he states that " the 1922 stock was the predominant element throughout, and even at the beginning of the summer growth in 1924 it formed over nine-tenths of the weight of the whole stock."

\section{Comparison of the Distribution of Tellina tenuis and TELLINA FABULA IN KAMES BAY.}

In Kames Bay both T. tenuis and T. fabula occur plentifully, but the relative frequency and area of distribution of the two species do not 
correspond. In the adjoining table the numbers of each species in the collections made during September, 1926, at Stns. 1 to 8 are given, along with those from stations in deeper water as far as the limit of the species.

TABLE 5.

Table showing the Numbers of T. TENUIS AND T. FABUla at various Stations in Kames Bay.

\begin{tabular}{lcrrr|rrrrrr} 
& \multicolumn{4}{c|}{ Contained in $\frac{1}{4}$ sq. m. } & \multicolumn{5}{c}{ Contained in 20 -cm. cube. } \\
Station & 2 & 3 & 4 & 5 & 6 & 7 & 8 & $7 \mathrm{fm}$. & $10 \mathrm{fm} .14 \mathrm{fm}$. \\
No. T. tenuis & 132 & 205 & 473 & 822 & 327 & 29 & - & - & - & - \\
No. T.fabula & - & - & 3 & 3 & 26 & 101 & 144 & 134 & 10 & -
\end{tabular}

Thus T. tenuis is abundant between tide marks and just below L.W.M., but dies away at greater depths, while $T$. fabula is sparingly distributed between tide marks but becomes abundant in depths of 4-6 fm., and dies away in turn about $11 \mathrm{fm}$. The growth-rate of Tellina fabula, for comparison with that of Tellina tenuis, has not yet been fully worked out, but it is probably of the same order as that of Tellina tenuis at Stn. 6.

VII. State of the Reproductive Organs.

Active spermatozoa were first noticed in a few individuals from between tide marks at the end of May when the ova were flat and compressed by crowding in the gonad. In July mature ova were found rounded off, while in August some specimens, both male and female, appeared more or less spent. No actual spawning was noticed.

In June small specimens of $7 \mathrm{~mm}$. length were found to have maturing gonads, showing the incidence of maturity in the 1+year group.

\section{Spat Fall.}

The state of the reproductive organs was taken to indicate that no young brood would appear on the bottom before about June, but, to make certain, sampling with a $1 \mathrm{~mm}$. sieve was conducted at, and above, L.W.M., a position shown by later studies to be rather an unfortunate one. Better results might have been obtained had the samples been taken below L.W.M.

No specimens of Tellina tenuis, passing the $2 \mathrm{~mm}$. sieve but retained by the $1 \mathrm{~mm}$. sieve, were found during the winter or spring months. In August, 1927, the whole 20-c.c. cube of sand dredged at Stns. 6, 7, and 8 was sieved through the two sieves as well as samples from Stns. 4 and 5 . The same observations were repeated in October, 1927, and, in addition, samples were taken from Stns. 3 and 2. The results are set out in the adjoining table. 
TABLE 6 .

Table showing the Numbers of Tellina tenuis passivg the 2-mm. SIEVE BUT RETAINED BY THE 1-MM. SIEVE.

\begin{tabular}{|c|c|c|c|c|c|c|c|c|}
\hline & \multicolumn{3}{|c|}{ Numbers in $20 \mathrm{~cm}$. cube } & \multicolumn{5}{|c|}{$\begin{array}{l}\text { Numbers in } \frac{1}{4} \mathrm{sq} . \mathrm{m} \text {. calculated from the } \\
\text { small samples. }\end{array}$} \\
\hline & 8 & 7 & 6 & 5 & 4 & 3 & 2 & la \\
\hline 1927 & 18 & 290 & 11 & 85 & 10 & - & - & - \\
\hline Oct., 1927 & 28 & 167 & 85 & 102 & 105 & 126 & 20 & 20 \\
\hline
\end{tabular}

These results indicate that the spat is deposited during the summer months in large numbers a little way below low-water mark, but by autumn it is also to be found spread in large numbers up to the half-tide mark, and in noticeably diminished numbers in the higher levels. Deposition probably lasts for a period of 2 to 3 months, but this point has still to be cleared up.

\section{Food.}

During the winter months the food consists almost entirely of debris, thalloid and filamentous algæ predominating, with some detritus from the land. Diatoms play a small part while, amongst other less important material, sponge spicules, starch grains, and sulphur bacteria occur, the latter probably derived from decaying algæ.

During the spring diatom increase the food consists entirely of diatoms, while during the early summer months the food is again mixed, but diatoms still predominate. Davis (4) has found similar results in the case of Spisula subtruncata; an examination of the stomach contents showed that these bore a great similarity to the detritus on the bank. These results are also in accord with the general conclusions of Blegvad (1).

\section{Mortality.}

No special study of the mortality has yet been made, but at all seasons a few dead valves, mostly attached by the ligament, are to be found in the samples. Only once, in June, 1927, at about half-tide, when many dead shells were seen mingled with the little heaps of debris and seaweed on the shore, was a special collection of the dead material made. Three hundred and thirty-eight valves of Tellina tenuis, ranging in size from $3 \mathrm{~mm}$. to $12 \mathrm{~mm}$., still attached by the ligament, were found, and in no case were these bored by Natica. In addition to these empty valves there were 56 specimens, ranging from $3 \mathrm{~mm}$. to $13 \mathrm{~mm}$., with the body still inside. In some the flesh was quite fresh, but in others it was black and decaying. This suggests that the mortality is due to "natural causes," 
and not to the action of Natica, such as Davis (5) has found in the case of Spisula, or of fishes, which frequently cause heavy mortality in the bivalve population.

\section{Conclusion.}

These results can only be regarded as preliminary, and there are many points in the life-history of Tellina tenuis still to be made out. This work was begun as part of a much larger scheme of investigation on the Clyde fauna, especially in regard to the age and renewal of certain groups of bottom-dwelling organisms, and to the numbers and season of appearance of the young broods. The attempt to work out the rate of growth and number of year-groups in the Tellina tenuis population by measurement and not by the study of annual rings is an initial step in the attempt to estimate the age of the bivalve population in Scottish waters. There is a great deal of uncertainty as to what the rings to be seen on the shells of certain species really indicate, and in other species these rings are not readily distinguishable. Hence it was felt that with such an abundance of Tellina tenuis available the study of the annual increment by measurement was possible. The results show that this is so, although confirmatory work is necessary to settle in how far the annual increment varies from season to season. Larger collections are necessary to secure adequate numbers of the older year-groups. The variation in the rate of growth from bay to bay is also important.

The search for the first appearances of the broods of various bivalves on the bottom is also being continued, certain areas being periodically examined with a fine sieve. In this way it should be possible to determine when and where spat is actually deposited. An attempt will also be made during the summer to trace the distribution of the larval stages of Tellina tenuis and of the sizes of less than $1 \mathrm{~mm}$. The early stages of this bivalve are probably pelagic, and, as bivalves of small size are taken in large numbers in the tow-net collections in the area, the identification of at least some of them should be possible.

\section{ACKNowledgments.}

To Mr. Elmhirst, the Superintendent of the Marine Station at Millport, I am indebted for the information in paragraphs VII and IX, and for the figures of the water-content of the sand in Kames Bay. I am also indebted to him for the facilities which I have enjoyed at the Marine Station; without his help in collecting the samples this work could not have been undertaken.

I have also to thank Dr. Ritchie of the Royal Scottish Museum for kindly reading the manuscript of this paper. 


\section{SUMMARY.}

1. The present paper deals with the results of investigations into certain phases in the life-history of the bivalve mollusc Tellina tenuis carried out during the autumn of 1926 and 1927.

2. Collections in the intertidal zone and below L.W.M., were made in a number of bays in the Cumbrae and neighbourhood, Kames Bay, Millport, being selected for intensive study.

3. In Kames Bay Tellina tenuis ranges from a little below H.W.M. to depths of about $4 \mathrm{fm}$. The maximum concentration of about 1000 per $\frac{1}{4}$ sq. m. is found at L.W.M. springs and the numbers decrease to zero at H.W.M. and $4 \mathrm{fm}$.

4. In Kames Bay the density of Tellina tenuis falls in a progressive manner from L.W.M. to H.W.M.

5. The size-frequency distribution shows a regular gradation from the lower to the higher levels. At L.W.M. and below individuals of small size predominate, while at H.W.M. they are proportionately few.

6. At higher levels growth is more rapid than at the lower levels.

7. The size-frequency curves and density of Tellina tenuis in the other bays at L.W.M. correspond with those of half-tide in Kames Bay.

8. The rate of growth may therefore be influenced by the density of population as well as by the habitat.

9. In all areas the 1926 brood predominates.

10. The Tellina tenuis population in Kames Bay seems to be composed of four year-groups, one of which is almost unrepresented. Collections from neighbouring bays indicate that older groups may be present.

11. The amount of young brood on the bottom seems to vary considerably from year to year, being large and small in alternate years.

12. The two closely related species, T. tenuis and T. fabula, are both plentiful in Kames Bay, but their range is not coincident.

13. Ripe sperms were found from May onwards and ova were rounding off in June.

14. Young Tellina tenuis, passing the $2-\mathrm{mm}$. sieve but retained by the 1-mm. sieve, were found in Kames Bay in August, chiefly below L.W.M., but in October plentifully distributed up to half-tide and in lesser numbers higher up the shore.

15. The food usually consists of vegetable detritus, but during the spring increase diatoms appear almost exclusively in the gut. 


\section{LITERATURE CITED.}

1. Blegvad, H. The Food and Conditions of Nourishment among the Invertebrate Animals in or on the Sea Bottom in Danish Waters. Rep. Danish Biol. Stn. XXII, 1914.

2. Boysen Jensen, P. Valuation of the Limfjord 1. Rep. Danish Biol. Stn. XXVI, 1919, p. 13.

3. Davis, F. M. Quantitative Studies on the Fauna of the Sea Bottom. No. 1, Preliminary Investigation of the Dogger Bank. Min. Agri. Fish. Invest., Series II, Vol. VI, No. 2, London, 1923.

4. Ibid., p. 26.

5. Ibid., p. 29-32.

6. Ford, E. On the Growth of Some Lamellibranchs in Relation to the Food Supply of Fishes. Journ. Mar. Biol., New Series, Vol. XIII, No. 3, March, 1925.

7. Ibid., p. 535 .

8. Ibid., p. 544 .

9. Gemmil, J. F. Communication Millport Marine Biol. Stn., Nov., 1900, pp. 34-35, or Report 79th Meeting British Association, 1899, p. 782 .

10. Segerstråle, Sven G. Societas Scientiarum Fennica Commentationes Biologicæ, II, 11. 


\section{TABLE 7.}

Table showing the Percentage of the Total Catch of Tellina tenuis at each Size-frequency IN mm. at Stations 2 to 7 in Kames Bay.

STN. 2.

\begin{tabular}{|c|c|c|c|c|c|c|c|c|c|c|c|c|c|c|c|c|c|}
\hline & & & & & & & & $\mathrm{m}$ & & & & & & & & & al \\
\hline & 3 & 4 & 5 & 6 & 7 & 8 & 9 & 10 & 11 & 12 & 13 & 14 & 15 & 16 & 17 & 18 & mens. \\
\hline & 3.0 & 6.0 & $11 \cdot 3$ & $3 \cdot 8$ & 0.8 & - & 0.8 & 6.0 & $12 \cdot 1$ & $9 \cdot 0$ & $20 \cdot 4$ & $12 \cdot 9$ & $10 \cdot 5$ & $1 \cdot 6$ & 0.8 & 0.8 & 132 \\
\hline & $12 \cdot 0$ & $23 \cdot 5$ & $13 \cdot 7$ & $1 \cdot 1$ & $3 \cdot 3$ & 0.6 & $1 \cdot 7$ & $3 \cdot 3$ & $9 \cdot 3$ & $8 \cdot 7$ & $10 \cdot 9$ & $7 \cdot 6$ & $4 \cdot 4$ & $=$ & 0.6 & - & 183 \\
\hline 1.27 & $26 \cdot 0$ & $18 \cdot 0$ & 10.7 & 6.6 & $2 \cdot 0$ & 0.7 & $1 \cdot 3$ & $2 \cdot 0$ & $4 \cdot 6$ & $6 \cdot 0$ & $8 \cdot 6$ & $7 \cdot 3$ & $4 \cdot 6$ & $2 \cdot 0$ & - & - & 151 \\
\hline .27 & $1 \cdot 2$ & $5 \cdot 4$ & $10 \cdot 7$ & $20 \cdot 2$ & $13 \cdot 7$ & $6 \cdot 6$ & $2 \cdot 4$ & 1.8 & 0.6 & $3 \cdot 6$ & 6. & $7 \cdot 1$ & $13 \cdot 1$ & $5 \cdot 4$ & $1 \cdot 2$ & 0.6 & 168 \\
\hline .27 & 0.5 & 0.5 & $4 \cdot 0$ & $9 \cdot 3$ & $15 \cdot 2$ & $18 \cdot 2$ & $18 \cdot 2$ & 8.4 & 1.5 & 0.5 & $7 \cdot 9$ & $4 \cdot 9$ & $4 \cdot 4$ & $3 \cdot 9$ & $2 \cdot 5$ & - & 203 \\
\hline 10.28 & - & $3 \cdot 1$ & $1 \cdot 0$ & $3 \cdot 1$ & $10 \cdot 3$ & $12 \cdot 4$ & $23 \cdot 6$ & 18.5 & $4 \cdot 2$ & $3 \cdot 1$ & $2 \cdot 0$ & $9 \cdot 3$ & $8 \cdot 3$ & $1 \cdot 0$ & - & - & 97 \\
\hline
\end{tabular}

\section{STN. 3.}

Total speci24.9 .26
20.1 .27 13.4 .27 14.6 .27 13.8.27 7.10 .27 $\begin{array}{lllllllllllllllll}3 & 4 & 5 & 6 & 7 & 8 & 9 & 10 & 11 & 12 & 13 & 14 & 15 & 16 & 17 & 18 & \text { mens. }\end{array}$

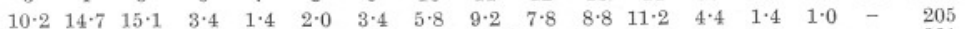
$\begin{array}{lllllllllllllllll}13.6 & 15.5 & 13.1 & 4.1 & 0.4 & 1.8 & 4.1 & 7.8 & 7.4 & 11.8 & 13.6 & 6.0 & 0.4 & 0.9 & - & - & 221\end{array}$

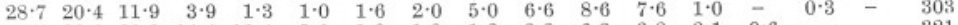

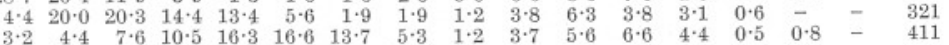

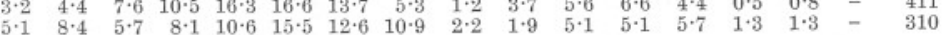

STN. 4.

Total speci-

24.9 .26 20.1.27 13.4.27 14.6 .27 13.8 .27 7.10 .27

\begin{tabular}{|c|c|c|c|c|c|c|c|c|c|c|c|c|c|c|c|c|}
\hline 3 & 4 & 5 & 6 & 7 & 8 & 9 & 10 & 11 & 12 & 13 & 14 & 15 & 16 & 17 & 18 & $\begin{array}{l}\text { speci- } \\
\text { mens. }\end{array}$ \\
\hline $36 \cdot 3$ & $19 \cdot 9$ & $7 \cdot 6$ & 1.2 & 0.9 & $3 \cdot 0$ & $7 \cdot 8$ & $8 \cdot 7$ & 8.2 & $5 \cdot 5$ & 0.9 & - & - & - & - & - & 473 \\
\hline $35 \cdot 0$ & $20 \cdot 3$ & $8 \cdot 1$ & $2 \cdot 9$ & 1.4 & $2 \cdot 7$ & 6.3 & $6 \cdot 3$ & 7. & 7. & $1 \cdot 9$ & - & - & - & - & - & 632 \\
\hline $36 \cdot 1$ & $20 \cdot 5$ & $10 \cdot 5$ & $4 \cdot 4$ & 0.9 & 0.9 & $3 \cdot 4$ & $4 \cdot 3$ & $5 \cdot 7$ & $5 \cdot 5$ & $6 \cdot 6$ & $1 \cdot 6$ & - & - & - & - & 560 \\
\hline $5 \cdot 4$ & $20-1$ & $25 \cdot 3$ & $17 \cdot 1$ & $11 \cdot 0$ & 3.8 & 1.0 & $4 \cdot 4$ & $4 \cdot 0$ & $3 \cdot 6$ & $2 \cdot 4$ & 1.5 & 0.4 & $\overline{-}$ & - & - & 742 \\
\hline $1 \cdot 7$ & $3 \cdot 7$ & $10 \cdot 7$ & $19 \cdot 3$ & 20.5 & $18 \cdot 8$ & $10 \cdot 3$ & $3 \cdot 3$ & $2 \cdot 3$ & $2 \cdot 8$ & $3 \cdot 2$ & 1.9 & $1 \cdot 4$ & 0.1 & - & - & 835 \\
\hline 2.0 & $3 \cdot 5$ & $6 \cdot 9$ & $14 \cdot 1$ & 16.8 & $18 \cdot 7$ & $13 \cdot 3$ & $5 \cdot 2$ & 3.5 & $6 \cdot 9$ & $5 \cdot 4$ & $2 \cdot 2$ & $1 \cdot 4$ & - & - & - & 594 \\
\hline
\end{tabular}

STN. 5.

Total $\begin{array}{lllllllllllllllll}3 & 4 & 5 & 6 & 7 & 8 & 9 & 10 & 11 & 12 & 13 & 14 & 15 & 16 & 17 & 18 & \text { mens. }\end{array}$ $\begin{array}{lllllllllllllllllll}24.9 .26 & 61.8 & 17.9 & 2.5 & 0.6 & 1.7 & 3.9 & 4.6 & 3.1 & 2.2 & 1.0 & 0.4 & - & 0.3 & - & - & - & 822\end{array}$ $\begin{array}{llllllllllllllllll}7.2 .27 & 49.7 & 20.2 & 5.0 & 1.8 & 1.9 & 3.5 & 5.7 & 5.3 & 4.3 & 2.1 & 0.3 & 0.1 & - & - & - & - & 905\end{array}$ $\begin{array}{llllllllllllllllll}13.4 .27 & 41.5 & 25.1 & 7.0 & 2.9 & 0.9 & 2.2 & 4.9 & 6.5 & 5.6 & 2.2 & 0.7 & 0.2 & 0.1 & - & - & - & 998\end{array}$ $\begin{array}{llllllllllllllllll}20.6 .27 & 4.6 & 18.1 & 23.7 & 17.9 & 10.8 & 4.2 & 1.6 & 4.9 & 6.1 & 4.9 & 2.9 & 0.4 & - & - & - & - & 736 \\ 1 & 13 & & & \end{array}$ $\begin{array}{llllllllllllllll}13.8 .27 & 13.1 & 5.3 & 12.3 & 17.9 & 15.7 & 10.4 & 4.8 & 6.9 & 6.7 & 4.1 & 1.9 & 0.9 & & & \\ 7\end{array}$

\section{STN. 6.} $\begin{array}{lllllllllllllllll}3 & 4 & 5 & 6 & 7 & 8 & 9 & 10 & 11 & 12 & 13 & 14 & 15 & 16 & 17 & 18 & \text { mens. }\end{array}$ $\begin{array}{lllllllllllllllllllll}6.10 .26 & 69.2 & 19.4 & 1.8 & 1.8 & 1.8 & 1.8 & 3.1 & 0.3 & 0.5 & - & - & - & - & - & - & - & 325\end{array}$ $\begin{array}{lllllllllllllllllll}17.4 .27 & * & 63.4 & 25.1 & 8.0 & 0.9 & 1.1 & 0.3 & 0.9 & - & - & 0.3 & - & - & - & - & - & - & 355\end{array}$

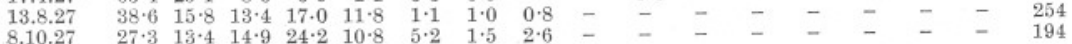

* In January, 1927, a cube of 20 c.c. only gave 3 specimens of $3 \mathrm{~mm}$. in length, but owing to the stormy weather when the haul was made it cannot be considered as a true sample.

STN. 7.

$\begin{array}{lllllllllllllllll}3 & 4 & 5 & 6 & 7 & 8 & 9 & 10 & 11 & 12 & 13 & 14 & 15 & 16 & 17 & 18 & \text { mens. }\end{array}$

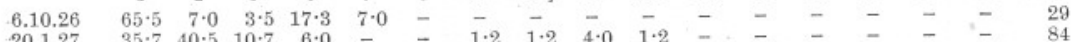

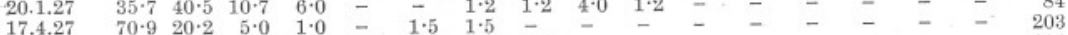

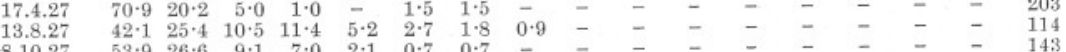

NEW SERIES.-VOL. XV. NO. 2. APRIL, 1928 


\section{TABLE 8 .}

Table showing the Percentage of the Total Catch of Tellina tenuls at each mm. at Certain Stations in the Fatrlie Sands, White Bay, Garrison Bay, and Castle Bay, Littue Cumbrae.

\begin{tabular}{|c|c|c|c|c|c|c|c|c|c|c|c|c|c|c|c|c|c|c|c|c|}
\hline 3 & 4 & 5 & 6 & 7 & 8 & 9 & 10 & 11 & 12 & 13 & 14 & 15 & 16 & 17 & 18 & 19 & 20 & 21 & 24 & $\begin{array}{l}\text { Total } \\
\text { speci- } \\
\text { mens. }\end{array}$ \\
\hline $0 \cdot 9$ & $8 \cdot 8$ & $20 \cdot 6$ & $22 \cdot 9$ & $15 \cdot 3$ & $9 \cdot 8$ & $2 \cdot 7$ & 0.9 & $0 \cdot 3$ & $0 \cdot 6$ & $1 \cdot 8$ & $2 \cdot 4$ & $3 \cdot 0$ & $3 \cdot 6$ & $3 \cdot 0$ & $1 \cdot 5$ & 1.5 & $0 \cdot 3$ & $0 \cdot 3$ & - & 339 \\
\hline $2 \cdot 9$ & $5 \cdot 7$ & $10 \cdot 3$ & $19 \cdot 8$ & $23 \cdot 7$ & $21 \cdot 7$ & $7 \cdot 7$ & $2 \cdot 1$ & 0.8 & $1 \cdot 0$ & 0.9 & 0.9 & $1 \cdot 1$ & 0.5 & $0 \cdot 3$ & $0 \cdot 1$ & $0 \cdot 3$ & - & - & - & 765 \\
\hline- & - & $1 \cdot 6$ & $11 \cdot 1$ & $14 \cdot 3$ & $6 \cdot 4$ & - & - & $1 \cdot 6$ & $6 \cdot 4$ & $9 \cdot 5$ & $12 \cdot 7$ & $15 \cdot 7$ & $1 \cdot 6$ & - & $7 \cdot 9$ & $1 \cdot 6$ & $6 \cdot 3$ & $3 \cdot 2$ & $1 \cdot 6$ & 242 \\
\hline
\end{tabular}

White Bay, L.W.M., 14.4.27 $\begin{array}{lllllllllllllllllllllll}5.4 & 28.5 & 26.0 & 11 \cdot 1 & 5.8 & 5.0 & 3.3 & 2.9 & 0.8 & 0.4 & 0.8 & 1.6 & 0.4 & 1.6 & 4 \cdot 1 & 0.4 & - & 0.8 & 0.3 & - & 218\end{array}$

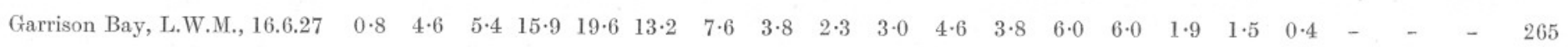

Castle Bay, Little Cumbrae, L.W.M. 18.6 .27

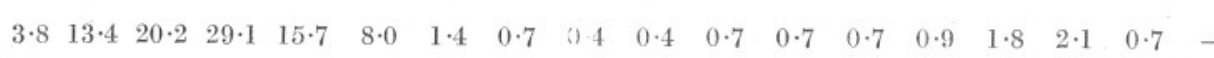

